\title{
Vulnerability of People's Livelihoods to Water Resources Availability in Semi Arid Areas of Tanzania
}

\author{
Shadrack Mwakalila \\ Department of Geography, University of Dar-es-Salaam, Dar es Salaam, Tanzania \\ E-mail:smwakalila@yahoo.com \\ Received July 3, 2011; revised August 6, 2011; accepted September 9, 2011
}

\begin{abstract}
In semi-arid areas of Tanzania vulnerability context is depicted as the starting component for policy process analysis through the sustainable livelihood approach. Giving vulnerability a high prominence in this analysis allowed the research to consider all kinds of vulnerabilities as central issues to the ways in which livelihoods are shaped. Hence the Sustainable Livelihood framework was used in this research as the comprehensive framework for assessing the contributing factors to limited water resources availability to sustain people's livelihoods. The study revealed that, changes in the quantity, timing, intensity and duration of rainfall as a result of climate change contributes to greater water stress and making people more vulnerable. Due to over-abstraction upstream of the Great Ruaha River, it implies that, people depending on the water resources downstream of the Great Ruaha River catchment are vulnerable. Their livelihoods are at risks as they don't have water for irrigation and other economic activities. The study also revealed that, both vulnerability and livelihood strategies are derived through natural water availability which features droughts, climate change and the link between water availability, agricultural production, and outcomes.
\end{abstract}

Keywords: Vulnerability, Livelihood, Water Resources, Great Ruaha Catchement

\section{Introduction}

In the Great Ruaha River catchment, cross-cutting issues such as poverty and water related issues call for a joined-up sense and exploration of the ways in which what happens across several different sectors contributes to or hampers the realization of particular policy objectives towards poverty reduction [1]. Management of the Great Ruaha River catchment in Tanzania calls for poverty considerations as well as for environmental, development and conservation objectives [2,3].

This is a positive way of thinking as it takes considerations of social and economic impacts of the technology promoted in developing the basin. The thinking move away from focusing on reduced run-off and flooding; erosion; enhancing groundwater recharge with little regard for livelihoods of people in the basin [4]. But, how environmental issues are understood is also changing. They are perceived as complex and adaptive systems that are characterized by transformative changes and uncertainty [5], a setting in which boundaries between ecological systems and social systems are dissolving [6]. Perceiving environmental issues in this way, give impe- tus to the debate on the opportunities and limitations of managing social changes. Livelihoods of the village are thus seen to depend on the environmental conditions. Acknowledging this livelihoods-environment linkage, the concept of social-ecological system becomes prominent in the Great Ruaha River natural resources governance. The term refers to systems of people and nature at the village where social and ecological processes are inextricably interrelated.

This study used the Sustainable Livelihood framework approach for assessing vulnerability of people's livelihoods to water resources availability. Drawing on [7,8], the use of livelihoods approach on this study premise on the fact that the livelihoods analysis for the water sector builds on the better understanding of the multiple perspective of water use and making water and land as capitals. Water is a natural capital (i.e. agricultural input, domestic needs); physical capital (i.e. irrigation infrastructure); social capital (i.e. water organizations, institutional, collective action); social capital as well as political capital. The approach was used to assess gains and losses of the rural poor from water reforms [9]. It was used to improve the knowledge of the context from the 
local level upwards and helped to analyze opportunities and constraints of the rural poor in the context of policy processes [10]. The approach helped to identify what options have better potential to reduce poverty within the given context and what enabling conditions, policies and incentives are needed for the poor to increase the range of better livelihoods options ([11-13]).

Some distinctive features of the livelihoods approach are that it takes an all-around view of people's means of gaining a living, including the social and institutional circumstances in which people's livelihoods is embedded. At the centre of the approach is a relationship between the assets or resources that people own or can obtain access to, including land, irrigation water, knowledge which are categorized as natural, human, social, financial and physical capitals. The household utilize these assets in their productive activities in order to create income and satisfy their consumption needs, maintain their asset level and invest in their future activities. The access to assets is strongly influenced by the vulnerability context, policies and institutions.

\section{The Study Area}

This study was carried out in the Great Ruaha River Catchment Areas (GRRCA) (Figure 1), which is subcatchment of the Rufiji River Basin in Tanzania. The Rufiji is the largest basin out of nine hydrological basins in Tanzania, with the drainage area of about $177,000 \mathrm{~km}^{2}$. It traverses five administrative regions and 13 administrative districts. The Great Ruaha covers an area of about $83,980 \mathrm{~km}^{2}$ which is $47 \%$ of the entire Rufiji Basin and its total runoff contributes about $15 \%$ of the annual flow of the Rufiji. Major rivers that drain the GRRCA are Kisigo, Great Ruaha, Little Ruaha, Mbarali, Kimani, Chimala, Mkoji, Ndembela, Lukosi, Yovi and Mwega (Figure 1).

The Great Ruaha River catchment area is home to about 6 million people. It contains the Usangu Plains, which lie at an average elevation of $1,100 \mathrm{~m}$ above sea level (asl), located between longitudes $33^{\circ} 00^{\prime} \mathrm{E}$ and $35^{\circ} 00^{\prime} \mathrm{E}$, and Latitudes $8^{\circ} 00^{\prime} \mathrm{S}$ and $9{ }^{\circ} 30^{\prime} \mathrm{S}$. The Plains are surrounded by Uporoto, Kipengere and Chunya

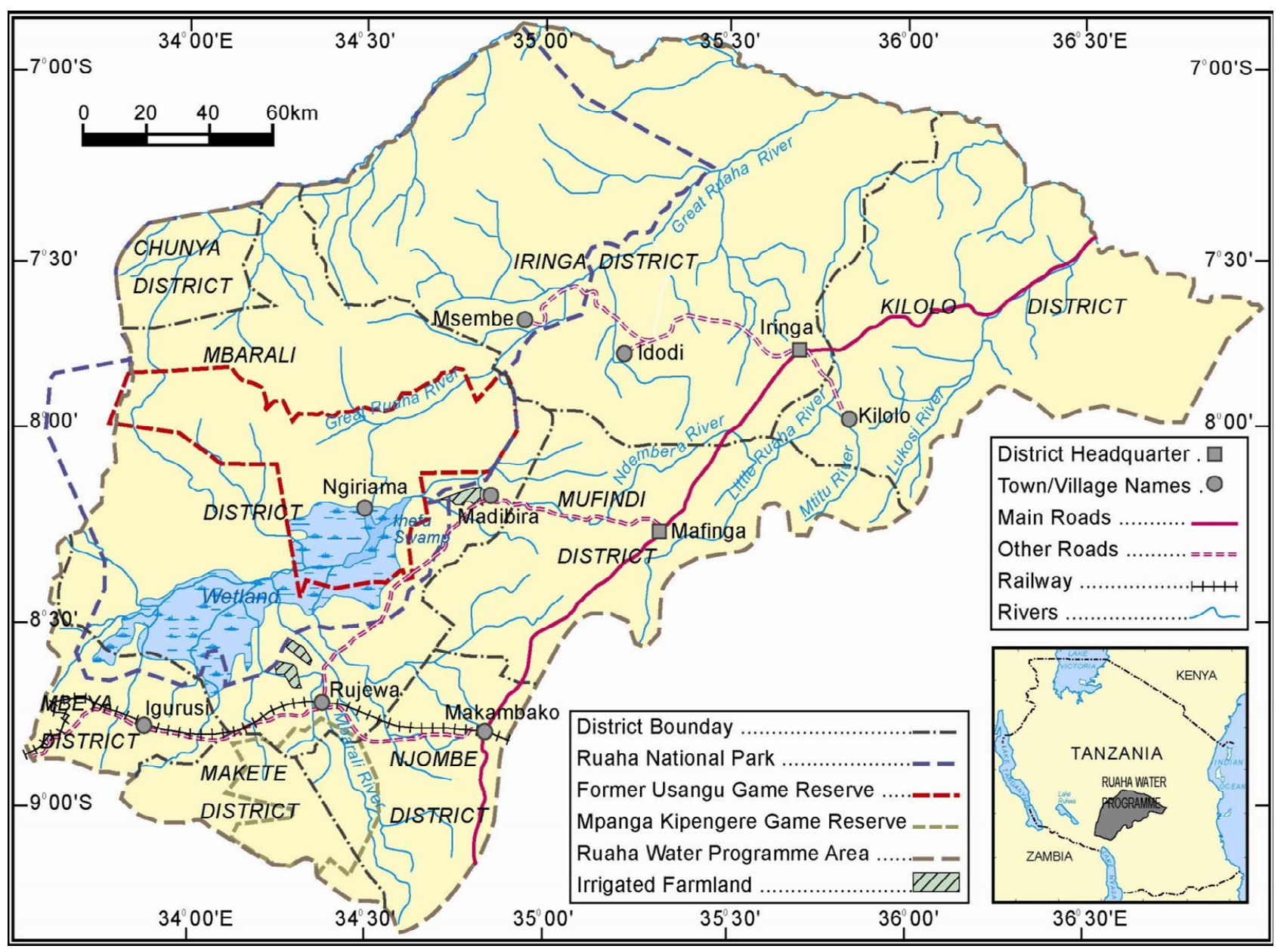

Figure 1. The Great Ruaha River Catchment. 
Mountains with elevations up to $3,000 \mathrm{~m}$ asl. The Usangu wetland and Ihefu wetland, Selous Game Reserve and Ruaha National Park depend on waters of the Great Ruaha River. These ecosystems are of both national and international importance as they are sources of foreign exchange and sustenance of livelihoods of the communities living in the Great Ruaha River catchment area [14].

\section{Methodology}

Several approaches were used in the collection of data for analysis. Both primary and secondary data was collected. Discussion with leaders was done prior to interview. This discussion was seen to be important to encourage their participation. Criterion for selection of representatives of villages had equal representation of village clusters, water user and gender. Key informants were selected based on the fact that they were knowledgeable on the issues of water management. Field survey was conducted on the Upper Great Ruaha River basin. The survey covered five rivers which are the source of water for irrigations on various schemes. The rivers include River Mlowo, Mambi, Lwanyo, Little Mkoji and Ipatagwa River. All these rivers feed their runoff to Mkoji River. The framework in Figure 2 below seeks to quantify livelihoods according to degrees of vulnerability, the quantity and nature of assets and the interaction of these aspects with policies, institutions and processes to establish livelihoods outcomes and strategies employed by households in communities. Understanding these factors provides a broad overview of the nature of poverty on the basin.

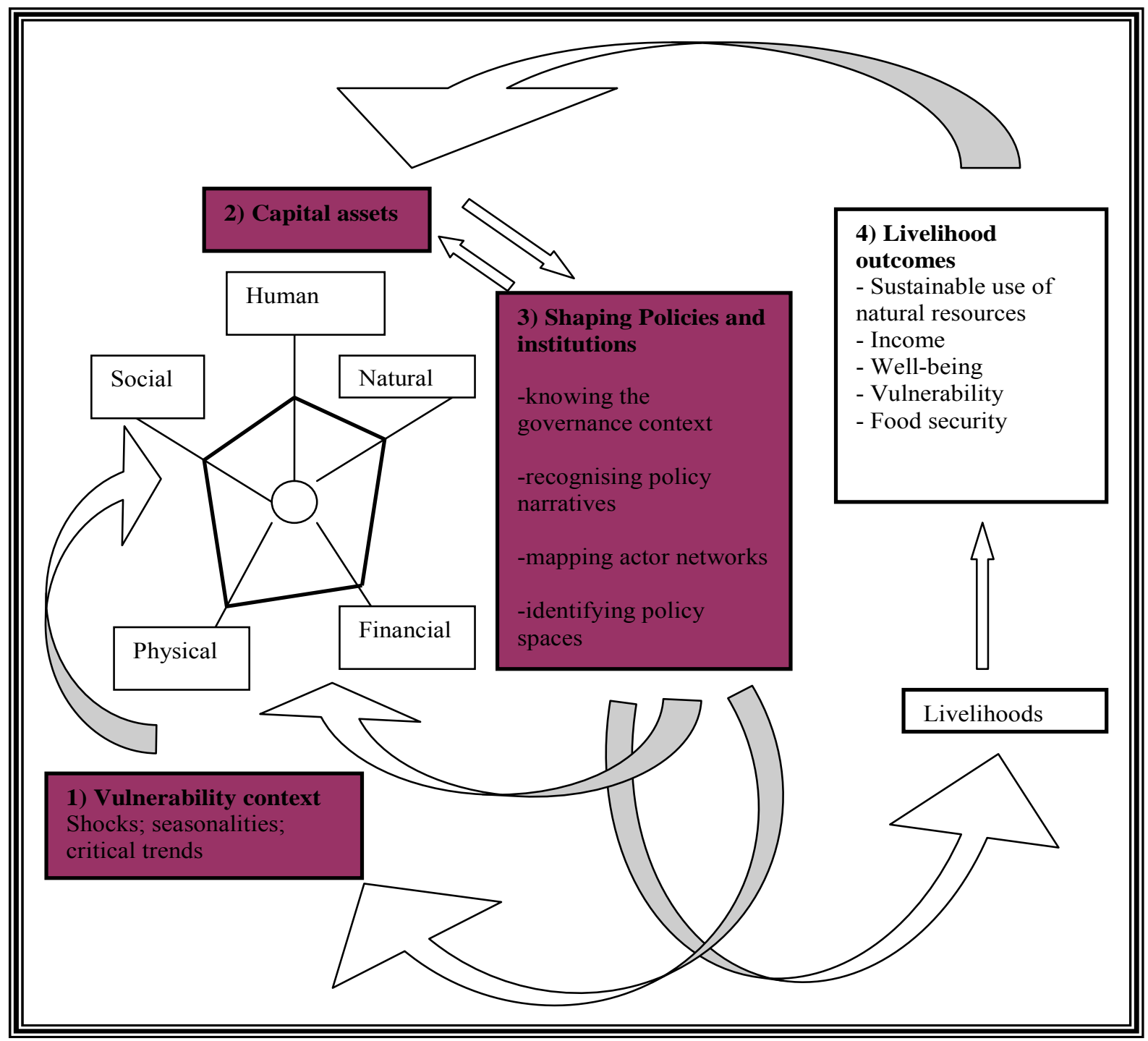

Figure 2. Livelihood framework for policy process analysis. 


\section{Results and Discussion}

\subsection{Vulnerability of People to Climate Changes}

The catchment experiences unimodal rainfall. Temperate conditions do exist in the southern highlands and high mountain ranges. Rainfall varies from $250-2000 \mathrm{~mm}$ per annum mainly from November to May. Rainfall amounts vary from year to year. Temperatures are quite varied too, in the highlands the temperature variability is high, and sometimes it freezes in some areas during the cold months. Table 1 presents some climatic characteristic from selected sites in the GRRCA.

It can be seen from Table 1 that in most of the sites presented annual rainfall is much less compared to potential evapo-transpiration, indicating a negative balance (i.e. moisture deficit). Such situation may be worsened by climate change. Climate change, population growth, increasing water demand, overexploitation of natural resources and environmental degradation have significantly degraded the world's freshwater resources [15]. Humans depend on the integrity of natural systems to provide the goods and services they need for survival. In many parts of the world, the limited availability of clean, fresh water is a major constraint to further social and economic development.

The availability of water is affected in many ways by climate change. For example, changes in the quantity, timing, intensity and duration of rainfall as a result of climate change will contribute to greater water stress in many in the basin and making people more vulnerable. For example, Figure 3 indicate that rainfall intensity on the upstream varies spatially. It is high on the upper zone compared to the lower zone. The figure also indicates that April - November period is a dry period whilst December - March is a rainy period. Likely hood of these periods to change with climate changes is high due to the fact that the changes will affect the hydrological cycle.
This will have effects on the timing of irrigation start and finish. It will affect even the water and land productivity of the area forcing to change the rules and regulations required to manage water on the catchments. In terms of perturbations, the upper zone faces high variations in rainfall (see Figure 3). All rivers that feed Great Ruaha River originate from this zone. The impact of these perturbations is to reduce the moisture content in the vadose zone which in turn alters the inflow to rivers.

\subsection{Vulnerability of People to Water Resource Availability}

The upstream catchment of the Great Ruaha River Basin consists of a number of rivers .Trends of Lunwa and Mlowo Rivers show an increasing long term trend of flow (Table 2). The trend of Lunwa River has a higher slope $\left(5.75 \mathrm{~m}^{3} /\right.$ year $)$ compared to that of Mlowo River $\left(1.5675 \mathrm{~m}^{3} /\right.$ year$)$. This analysis gives a clear picture that Mswiswi River is more vulnerable to external aspects than Lunwa and Mlowo Rivers. This can be associated may with abstraction of water for irrigation on the upstream catchment. Analysis of runoff from gauging station 1KA16a, 1KA51a and 1KA50a for rivers Lunwa, Mlowo and Mswiswi respectively reveal that water is available but, is variable. Figure 4 indicates how the total runoffs of the three rivers change from year to year. The long term trend of the rivers indicates an increasing runoff for the period of year 1950 to 2005 . The changes in the runoffs depict the variability of the resource to be converted into livelihoods outcomes in the catchments. However, the overall picture that is portrayed by this figure is that water is available for irrigation purposes. This has an implication that water is even plenty in the Mkoji River which feeds the Great Ruaha River though this is not the case.

The severity of over-abstraction is as shown on Figure 5. This situation was captured during the site visit that

Table 1. Climatic characteristics of some areas in the Great Ruaha Catchment.

\begin{tabular}{ccccc}
\hline Station name & Altitude (masl) & Mean annual potential evaporation (mm) & Mean annual rainfall (mm) & Moisture deficit \\
\hline Nduli & 1428 & 1919 & 650 & -1269 \\
Mbeya & 1750 & 1713 & 965 & -748 \\
Igawa & 1150 & 2038 & 752 & -1286 \\
Mbarali & 1050 & 2391 & 638 & -1753 \\
Sao Hill & 1980 & 1592 & 900 & -692 \\
Njombe & 1900 & 1458 & 1200 & -258 \\
Mtera & 683 & 2261 & 560 & -1701 \\
\hline
\end{tabular}

Source: Rufiji Basin Water Office-2010. 


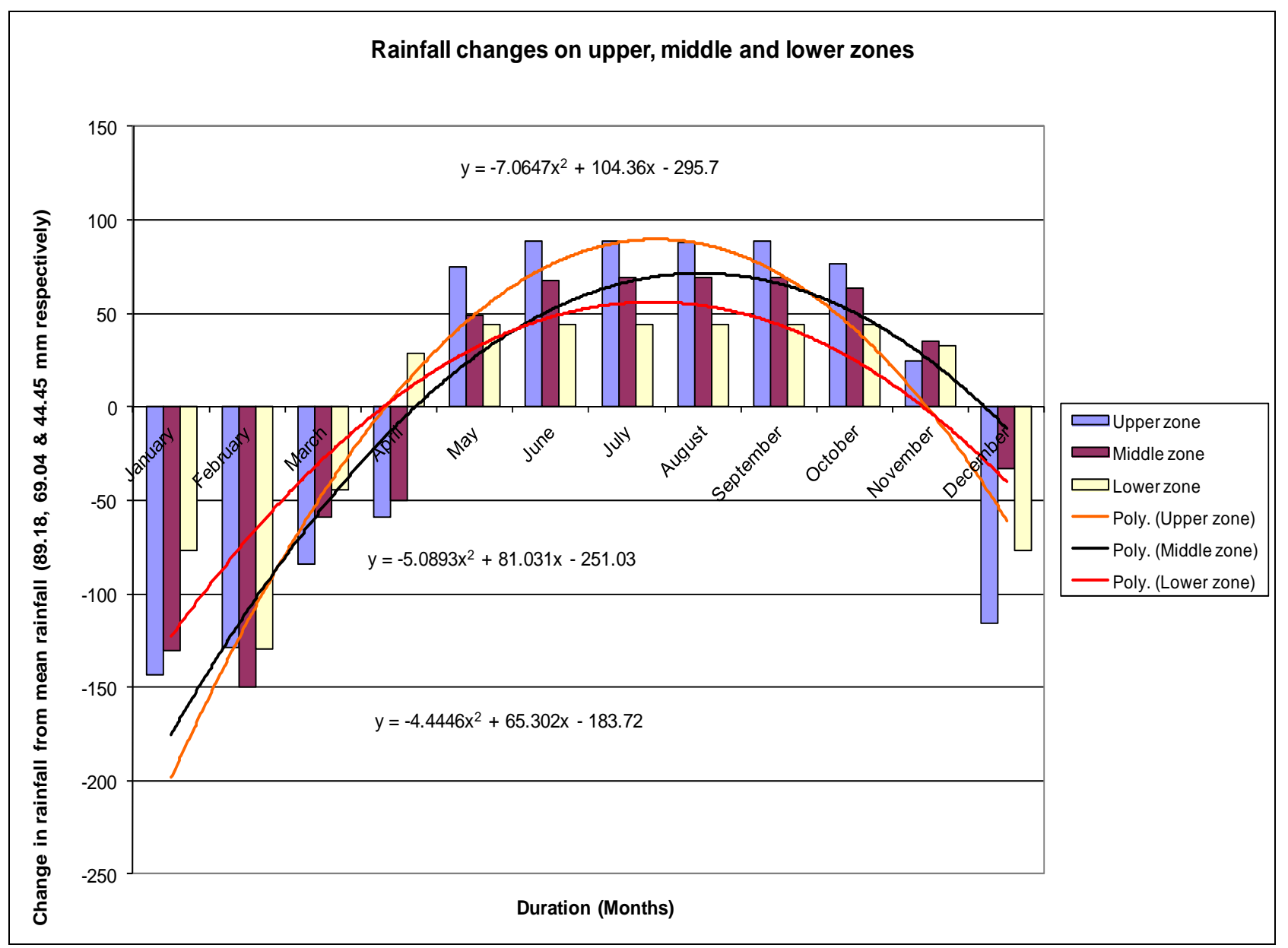

Figure 3. Rainfall changes on the upstream catchments.

Table 3. Linear trend analysis for Lunwa, Mswiswi and Mlowo rivers.

\begin{tabular}{cccccccc}
\hline Station name & $\begin{array}{c}\text { No. of } \\
\text { years }\end{array}$ & $\begin{array}{c}\text { Mean annual } \\
\text { flow }\left(\mathrm{m}^{3} / \mathrm{s}\right)\end{array}$ & $\begin{array}{c}\text { Slope of the trend line } \\
\left(\mathrm{m}^{3} / \text { year }\right)\end{array}$ & t-statistic & t-critical & Significant level & Remarks \\
\hline $\begin{array}{c}\text { Mlowo } \\
\text { 1KA51a }\end{array}$ & 46 & 245.16 & 1.56 & 2.15 & 2.01 & 0.05 & Significant increasing trend \\
$\begin{array}{c}\text { Mswiswi } \\
\text { 1KA50a }\end{array}$ & 46 & 412.56 & -1.59 & -0.97 & 2.01 & 0.05 & Insignificant trend \\
$\begin{array}{c}\text { Lunwa } \\
\text { 1KA16a }\end{array}$ & 46 & 516.49 & 5.74 & 2.1 & 2.01 & 0.05 & Significant increasing trend \\
\hline
\end{tabular}

was conducted from Uyole irrigaion scheme in Mbeya district to irrigation schemes on Mambi River in Mbalalidistrict. At Uyole irrigation scheme all river water was diverted to the irrigation scheme leaving no water on the natural Mwambalizi River at Uyole, Mbeya district.

With this analysis, it is clear that people depending on the lower part of all rivers situated on the upper part of the Great Ruaha River catchment are vulnerable. Their livelihoods are at risks as they don't have water for irrigation and other activities. And, how is water being allocated among different people across one river. In urg- ing towards the newly formulated narrative, this study puts forward the importance of water availability and productivity of water in relation to livelihood of people in the basin. The network shown on Figure 6 below indicates that a natural asset is meant to encompass all natural resources other than natural water which is excluded explicitly. Physical asset also, encompasses all physical assets other than water infrastructures. Production has no link to the capital assets because it is a direct consequence of water availability and water productivity which are being influenced by the capital assets. Water 


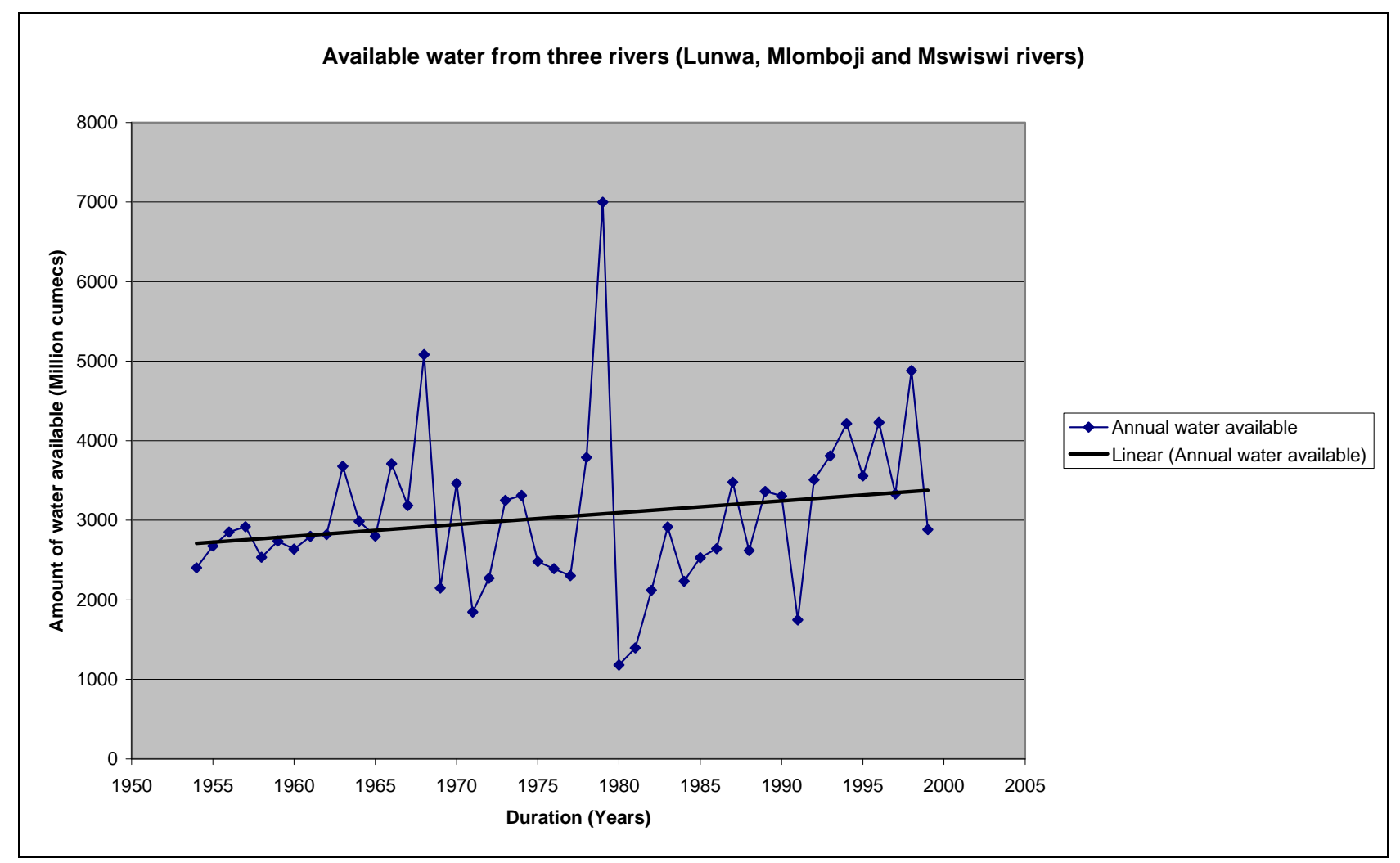

Figure 4. Available water from Lunwa, Mlowo and Mswiswi Rivers.

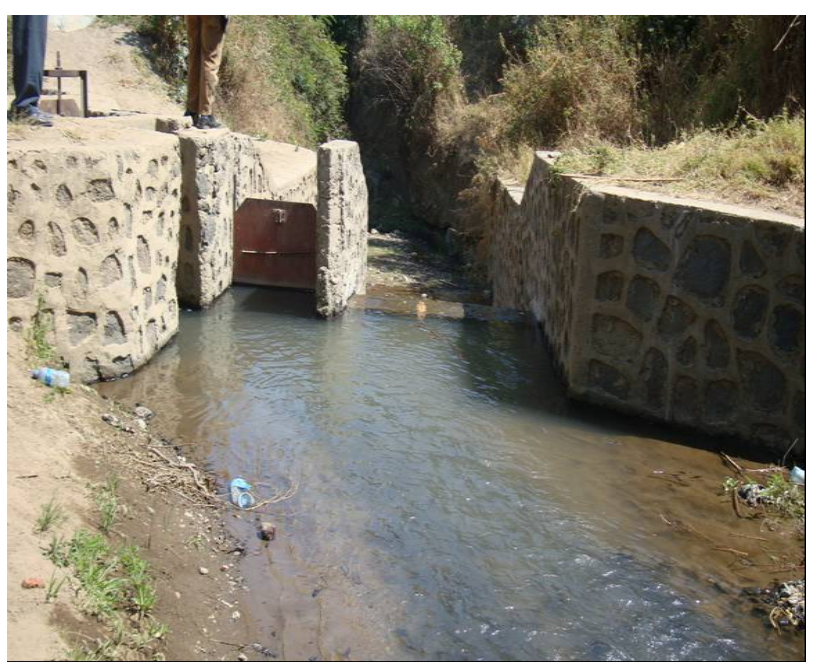

Figure 5. Over abstraction of water on Mwambalizi River.

availability is influenced by natural capital (natural water availability) and physical capital (water infrastructures) as well as social capital. Water productivity is affected by water infrastructure, and other physical capital, as well as financial, natural, and human capital. The network indicates that capitals mediate between production and livelihood outcomes of people. The network in Figure 6 has focused on the connection between livelihoods assets, water and livelihood outcomes. Both vulnerability and livelihood strategies are derived through natural water availability which features droughts, climate change and the link between water availability, agricultural production, and outcomes.

\section{Conclusions}

It can be concluded that all rivers on the upstream of the Great Ruaha River are vulnerable. Changes in the quantity, timing, intensity and duration of rainfall as a result of climate change contributes to greater water stress and making people more vulnerable. It is the dryness of the rivers and over abstraction at upstream that renders most rivers at risks. This implies that, people depending on the water resources downstream of the Great Ruaha River catchment are vulnerable. Their livelihoods are at risks as they don't have water for irrigation and other economic activities. This calls for sustainable natural resources management upstream of the Great Ruaha Catchment.

\section{Acknowledgements}

The author wish to acknowledge financial support received from REPOA-Tanzania. The author is grateful to 


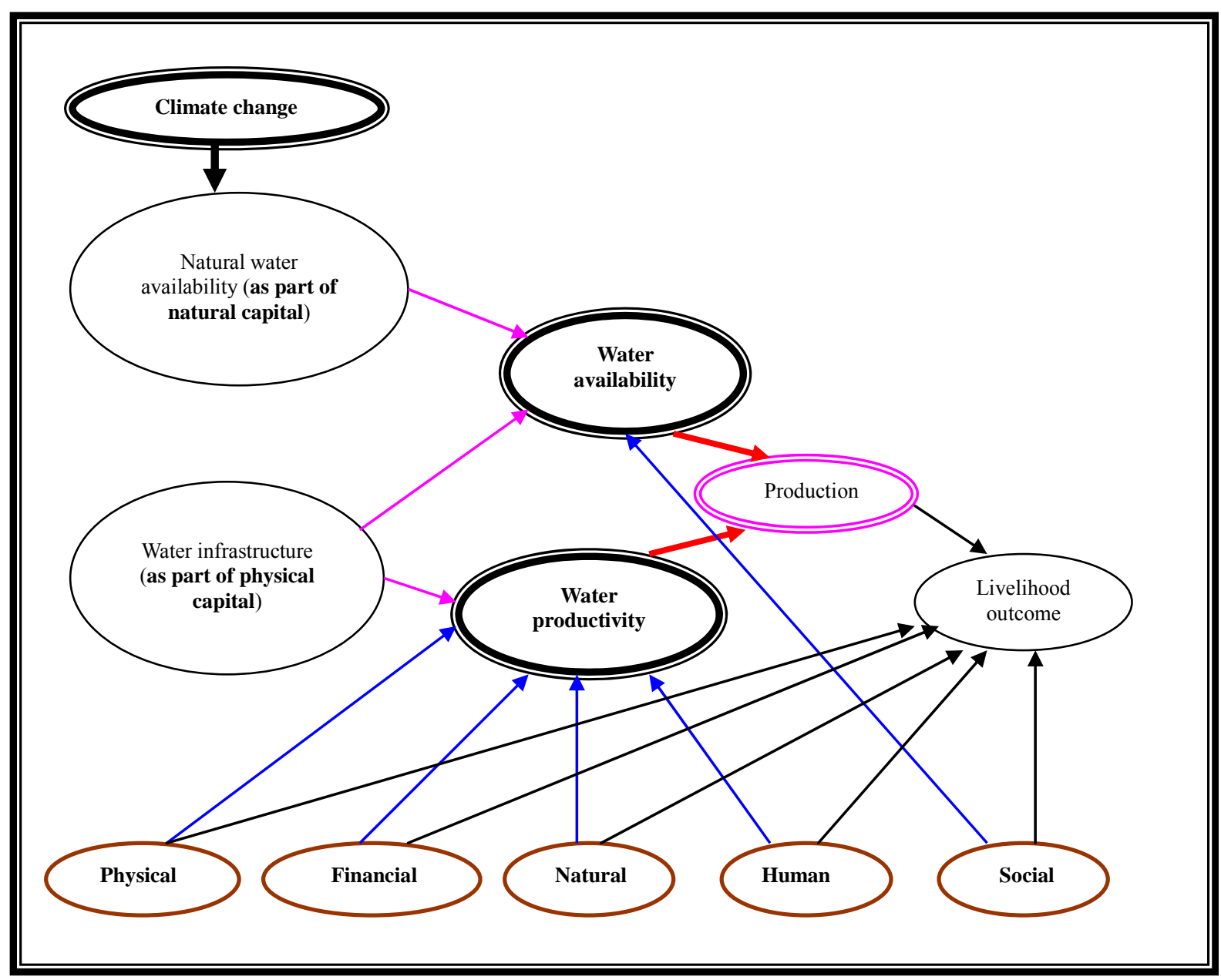

Figure 6. Basic links between water and livelihoods.

Mark Mwashihava for the valuable contribution on data collection.

\section{References}

[1] J. Keeley, "Influencing Policy Processes for Sustainable Livelihoods," Strategies for Change, 2001.

[2] United Republic of Tanzania, "Water Policy," 2002.

[3] L. Tennyson and P. C. Zingari, "Preparing for the Next Generation of Watershed Management Programmes and Projects," Watershed Management and Sustainable Development Working Paper No. 9, Food and Agriculture Organisation, Rome, 2006.

[4] S. S. Mwakalila, "Socio-Economic Impacts of Irrigated Agriculture in Mbarali District of South-West Tanzania," Journal of Physics and Chemistry of the Earth, Vol. 31. pp. 876-884.

[5] B. Holling, J. Walker, F. Bengtsson, J. Berkes, K. Colding, M. Danell, L. Falkenmark, R. E. Gordon, N. Kasperson, A. Kautsky, S. Kinzig, S. K. G. Levin, F. Mäler, P. Moberg, L. Ohlsson, E. Olsson, W. Ostrom, J. Reid, S. Rockstr\&öm, S. Savenije and U. Svedin, "Resilience and
Sustainable Development: Building Adaptive Capacity in a World of Transformations," AMBIO: A Journal of the Human Environment, Vol. 31, No. 5, 2002, pp. 437-440.

[6] F. Berkes, J. Colding and C. Folke, "Navigating SocialEcological Systems: Building Resilience for Complexity and Change," Cambridge University Press, Cambridge, UK, 2003.

[7] F. Cleave and T. Franks, "How Institution Elude Design: River Basin Management and Sustainable Livelihoods," BCID Research Paper No. 12, Bradford Centre for International Development, University of Bradford UK, 2003.

[8] F. Ellis and H. Freeman, "Conceptual Framework and Overview of Themes," In: F. Ellis and H. Freeman, Eds., Rural Livelihoods and Poverty Reduction Polices, Routledge, London and New York, 2005.

[9] B. Lankford, "Irrigation, Livelihoods and River Basins," In: F. Ellis and H. Freeman, Eds., Rural Livelihoods and Poverty Reduction Policies, Routledge, London and New York, 2005, pp. 274-293.

[10] Nicol, "Adopting a Sustainable Livelihoods Approach to Water Projects," Implications for Policy and Practice, Working Paper, No. 133, Overseas Development Institute 
(ODI), London, 2000.

[11] F. Ellis, "Livelihoods, Diversification and Agrarian Change, Rural Livelihoods and Diversity in Development Countries," Oxford University Press, New York, 2000.

[12] P. Moriarty, J. Butterworth, B. van Koppen and J. Soussan, "Water, Poverty and Productive Uses of Water at the Household Level," In: P. Moriarty, J. Butterworth and B. van Koppen, Eds., Beyond Domestic. Case Studies on Poverty and Productive Uses of Water at the Household Level, International Water and Sanitation Centre, The Netherlands, 2004.
[13] S. S. Mwakalila, "Water Resource Use in the Great Ruaha Basin of Tanzania," Journal of Physics and Chemistry of the Earth, Vol. 30, No. 11-16, 2005, pp. 903-912. doi:10.1016/j.pce.2005.08.037

[14] S. S. Mwakalila, "Opportunities and Challenges for Sustainable Water Resources Management in Tanzania," Geographical Journal, Vol. 174, No. 2, 2008, pp. 149175. doi:10.1111/j.1475-4959.2008.00286.x

[15] S. N. Ngigi, "Climate Change Adaptation Strategies," Water Resources Management Options for Smallholder Farming Systems in Sub-Saharan Africa, 2009. 